\title{
Modelling the impacts of European emission and climate change scenarios on acid-sensitive catchments in Finland
}

\author{
M. Posch ${ }^{1}$, J. Aherne ${ }^{2}$, M. Forsius ${ }^{3}$, S. Fronzek ${ }^{3}$, and N. Veijalainen ${ }^{3}$ \\ ${ }^{1}$ Coordination Centre for Effects, PBL, P.O. Box 303, 3720 AH Bilthoven, The Netherlands \\ ${ }^{2}$ Environmental and Resource Studies, Trent University, Peterborough, Ontario K9J 7B8, Canada \\ ${ }^{3}$ Finnish Environment Institute (SYKE), P.O. Box 140, 00251 Helsinki, Finland
}

Received: 18 December 2006 - Published in Hydrol. Earth Syst. Sci. Discuss.: 11 September 2007

Revised: 20 January 2008 - Accepted: 5 February 2008 - Published: 5 March 2008

\begin{abstract}
The dynamic hydro-chemical Model of Acidification of Groundwater in Catchments (MAGIC) was used to predict the response of 163 Finnish lake catchments to future acidic deposition and climatic change scenarios. Future deposition was assumed to follow current European emission reduction policies and a scenario based on maximum (technologically) feasible reductions (MFR). Future climate (temperature and precipitation) was derived from the HadAM3 and ECHAM4/OPYC3 general circulation models under two global scenarios of the Intergovernmental Panel on Climate Change (IPCC: A2 and B2). The combinations resulting in the widest range of future changes were used for simulations, i.e., the A2 scenario results from ECHAM4/OPYC3 (highest predicted change) and B2 results from HadAM3 (lowest predicted change). Future scenarios for catchment runoff were obtained from the Finnish watershed simulation and forecasting system. The potential influence of future changes in surface water organic carbon concentrations was also explored using simple empirical relationships based on temperature and sulphate deposition. Surprisingly, current emission reduction policies hardly show any future recovery; however, significant chemical recovery of soil and surface water from acidification was predicted under the MFR emission scenario. The direct influence of climate change (temperate and precipitation) on recovery was negligible, as runoff hardly changed; greater precipitation is offset by increased evapotranspiration due to higher temperatures. However, two exploratory empirical DOC models indicated that changes in sulphur deposition or temperature could have a confounding influence on the recovery of surface waters from acidification, and that the corresponding increases in DOC concentrations may offset the recovery in $\mathrm{pH}$ due to reductions in acidifying depositions.
\end{abstract}

Correspondence to: $\mathrm{M}$. Posch

(max.posch@mnp.nl)

\section{Introduction}

In Finland there has been a substantial decrease in sulphate $\left(\mathrm{SO}_{4}^{2-}\right)$ deposition (30\% in northern and up to $60 \%$ in southern Finland) since the late 1980s (Vuorenmaa, 2004) owing to large reductions in sulphur (S) emissions in both Finland and Europe in general. European emissions of $\mathrm{S}$ and nitrogen $(\mathrm{N})$ oxides, and ammonia $\left(\mathrm{NH}_{3}\right)$ have declined by $67 \%$, $24 \%$ and 20\%, respectively, between the years 1980 and 2000 (EMEP, 2004). The protocols to the Convention on Longrange Transboundary Air Pollution (LRTAP) of the United Nations Economic Commission for Europe (UNECE) and legislation of the European Union (EU) have been the key international instruments driving this development. In Finland, observed decreases in $\mathrm{N}$ deposition (monitored by the Finnish Environmental Institute, SYKE) are lower than for $\mathrm{SO}_{4}^{2-}$ due to the smaller reductions in precursor emissions. Nitrate $\left(\mathrm{NO}_{3}^{-}\right)$in bulk precipitation has decreased by 30 $40 \%$ in southern, $20-40 \%$ in central and $20-30 \%$ in northern Finland since the late $1980 \mathrm{~s}$. Ammonium $\left(\mathrm{NH}_{4}^{+}\right)$deposition has also shown a decreasing trend $(40-50 \%$ in southern, $30-50 \%$ in central and $30 \%$ in northern Finland) during the same period (Forsius et al., 2003; Vuorenmaa, 2004). Precipitation monitoring results of the Finnish Meteorological Institute show similar trends (Ruoho-Airola et al., 2003).

Reductions in acidifying depositions (primarily driven by reductions in $\mathrm{S}$ deposition) have resulted in large-scale recovery of lakes and streams from acidification across Europe and North America (e.g., Stoddard et al., 1999, 2003; Skjelkvåle et al., 2003, 2005). In concert, surface waters in Finland have shown (chemical) recovery from acidification. Mannio (2001) detected a statistically significant decline in $\mathrm{SO}_{4}^{2-}$ concentrations in $60-80 \%$ of the lakes in the Finnish lake acidification monitoring network (RMLA), depending on region. Forsius et al. (2003) estimated that some 1400 lakes of

Published by Copernicus Publications on behalf of the European Geosciences Union. 


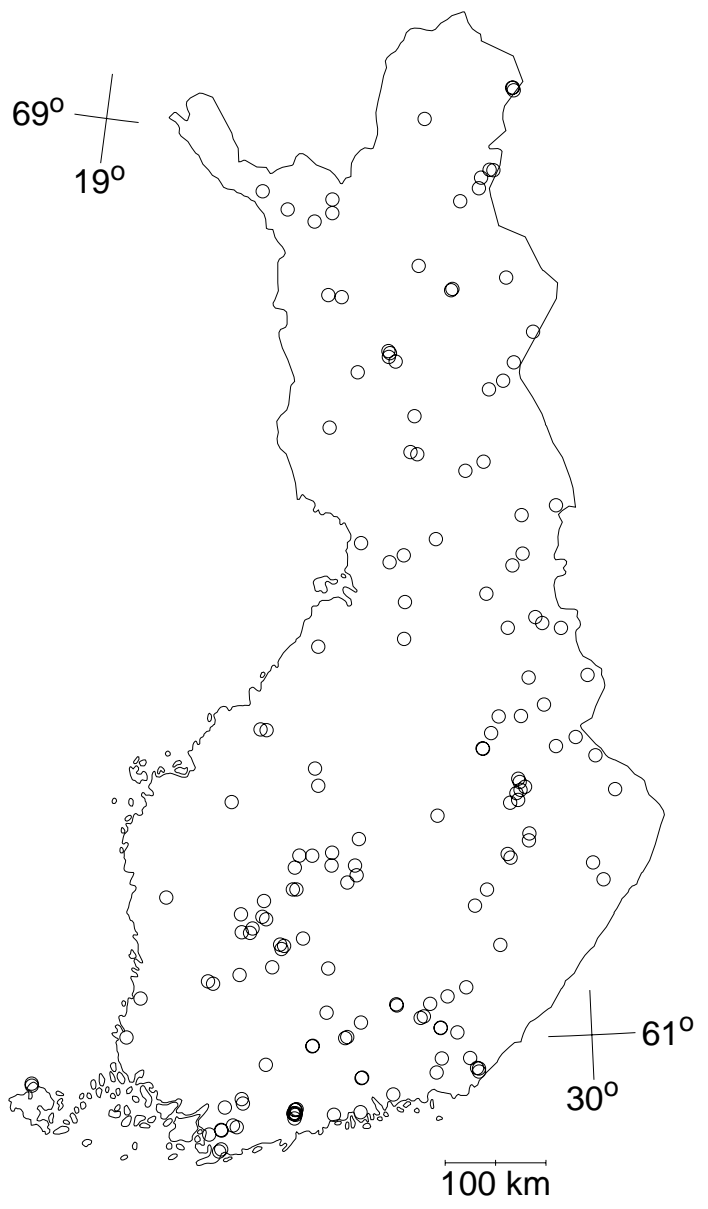

Fig. 1. Location of the 163 Finnish lake acidification monitoring network (RLMA) catchments used in this study (see Table 1 on catchment characteristics, lake-specific climate variables and average lake chemistry).

size $4-100$ ha (27\% of Finnish headwaters) have shown an increase in Gran alkalinity during the 1990s. The first signs of a (biological) recovery of perch (Perca fluviatilis) populations have also been recorded (Rask et al., 2001).

Further reductions in acidifying emissions are expected to result in continued recovery of acid sensitive ecosystems. It is anticipated that implementation of the 1999 Gothenburg Protocol under the Convention on LRTAP will cut European $\mathrm{S}$ emissions by at least $63 \%, \mathrm{~N}$ oxides by $41 \%$ and $\mathrm{NH}_{3}$ by $17 \%$ by the year 2010 , compared to 1990 . To evaluate the time-scales of future (chemical) response for soils and surface waters to the resulting changes in deposition, dynamic process-oriented models are required. Several dynamic (hydro-chemical) models, such as MAGIC (Model of Acidification of Groundwater in Catchments: Cosby et al., 1985, 2001), SAFE (Soil Acidification in Forest Ecosystems: Warfvinge et al., 1993) and SMART (Simulation Model of Acidification's Regional Trends: De Vries et al., 1989), have been developed and extensively applied at site-specific and regional scales to predict changes in soil and surface water chemistry (e.g., De Vries et al., 1994; Alveteg et al., 1995; Aherne et al., 2003; Wright et al., 2005). Recently, dynamic modelling has also become an important part of the effectsoriented work under the LRTAP Convention (Hettelingh et al., 2007). In Finland, SMART has been extensively used to model the response of soils and surface waters at site-specific (Iivonen et al., 1993; Kämäri et al., 1995, 1998; Forsius et al., 1997; Holmberg et al., 2000) and regional scales (Posch et al., 2003). The SMART, SAFE and MAGIC models have also been compared at a few Finnish monitoring sites (Warfvinge et al., 1992; Forsius et al., 1998). More recently, MAGIC has been calibrated to the RMLA lakes ( $\mathrm{n}=163$; Aherne et al., 2008) to assess future water chemistry.

There are a number of factors that can influence the extent of chemical recovery from acidification (Beier et al., 2003; Evans, 2005; Larssen, 2005; Skjelkvåle et al., 2005; Aherne et al., 2004, 2006). In general, modelling studies assume a constant influence of climate; however, there is a high probability that during the coming decades climate will change and have a confounding effect on chemical recovery from acidification. Changes in temperature, precipitation and storminess can all affect surface water chemistry directly, as well as indirectly through changes in vegetation and soils of the terrestrial catchments. Climate change projections for Finland based on six general circulation models (GCMs) give a range of increases for mean annual temperature between $2.4^{\circ} \mathrm{C}$ and $7.4^{\circ} \mathrm{C}$ and for annual precipitation of $6 \%$ to $34 \%$ between the baseline period 1961-1990 and the period 2070-2099 (Jylhä et al., 2004). The confounding influence of increasing dissolved organic carbon (DOC) concentrations has recently received considerable attention (Skjelkvåle et al., 2003, 2005; Worrall et al., 2004; Evans et al., 2006; Roulet and Moore, 2006; Vuorenmaa et al., 2006). It has been hypothesised that factors related to climate change may be (somewhat) responsible for the increases in DOC (Freeman et al., 2001a, b, 2004; Hejzlar et al., 2003; Evans et al., 2005; Holmberg et al., 2006), which have been observed across Europe and eastern North America during the past 10-20 years (Stoddard et al., 2003). Clearly, greater consideration of climatic effects (and climate variability) on biogeochemical cycles should be considered when predicting the recovery of acidified soils and surface waters (Forsius et al., 1997; Evans, 2005; Aherne et al., 2006; Wright et al., 2006).

This paper presents a regional application of MAGIC to 163 RMLA lakes in Finland. The objective of the study was to evaluate the impacts of future acid deposition and climate change scenarios on soil and surface water chemistry. The regional model inputs, data processing and model calibration are described in detail elsewhere (Aherne et al., 2008). Future deposition was assumed to follow current European emission reduction policies and a scenario based on maximum technologically feasible reductions (Amann et al., 2005). Future climate change (temperature and precipitation) was derived from the HadAM3 and ECHAM4/OPYC3 
Table 1. Statistical summaries (5th percentile, median and 95th percentile) for catchment characteristics, soil properties, long-term net removal in forest biomass, climate variables and annual average lake chemistry (2000-2004) for the RMLA lakes (n=163; see Fig. 1 for locations).

\begin{tabular}{|c|c|c|c|c|}
\hline Variable & Unit & 5 percentile & Median & 95 percentile \\
\hline Catchment area & ha & 21.28 & 108.6 & 797.2 \\
\hline Forest area & $\%$ terrestrial area & 35.1 & 74.7 & 97.0 \\
\hline Peatland area & $\%$ terrestrial area & 0.4 & 14.7 & 60.6 \\
\hline Soil depth & $\mathrm{m}$ & 0.26 & 0.49 & 0.67 \\
\hline Soil bulk density & $\mathrm{kg} \mathrm{m}^{-3}$ & 826.4 & 1008.7 & 1196.5 \\
\hline Cation exchange capacity (CEC) & meq $\mathrm{kg}^{-1}$ & 8.52 & 17.10 & 36.69 \\
\hline Soil base saturation & $\%$ CEC & 25.87 & 41.20 & 58.81 \\
\hline Net base cation uptake & meq $\mathrm{m}^{-2} \mathrm{yr}^{-1}$ & 0.89 & 6.38 & 14.57 \\
\hline Net nitrogen uptake & meq $\mathrm{m}^{-2} \mathrm{yr}^{-1}$ & 0.51 & 5.26 & 11.19 \\
\hline Lake area & ha & 2.3 & 10.0 & 137.3 \\
\hline Maximum lake depth & $\mathrm{m}$ & 1.61 & 5.4 & 20.35 \\
\hline Retention time & year & 0.08 & 0.88 & 6.05 \\
\hline Catchment runoff & $\mathrm{m}$ & 0.243 & 0.331 & 0.420 \\
\hline Precipitation & $\mathrm{m}$ & 0.482 & 0.608 & 0.701 \\
\hline Temperature & ${ }^{\circ} \mathrm{C}$ & -2.3 & 2.2 & 4.4 \\
\hline Calcium & $\mu$ eq $\mathrm{L}^{-1}$ & 11.00 & 63.87 & 143.21 \\
\hline Magnesium & $\mu$ eq $\mathrm{L}^{-1}$ & 8.23 & 39.49 & 80.09 \\
\hline Sodium & $\mu$ eq $\mathrm{L}^{-1}$ & 14.94 & 47.85 & 106.85 \\
\hline Potassium & $\mu$ eq $\mathrm{L}^{-1}$ & 2.30 & 8.70 & 18.71 \\
\hline Ammonium & $\mu$ eq $\mathrm{L}^{-1}$ & 0.20 & 0.64 & 3.13 \\
\hline Sulphate & $\mu$ eq $\mathrm{L}^{-1}$ & 13.10 & 45.82 & 118.64 \\
\hline Chloride & $\mu$ eq $\mathrm{L}^{-1}$ & 9.03 & 21.44 & 81.24 \\
\hline Nitrate & $\mu$ eq $\mathrm{L}^{-1}$ & 0.11 & 0.61 & 2.62 \\
\hline Acid neutralising capacity $*$ & $\mu$ eq $\mathrm{L}^{-1}$ & 0.84 & 78.97 & 181.72 \\
\hline $\mathrm{pH}$ (pondus Hydrogenii) & $\mathrm{pH}$ units & 4.87 & 5.84 & 6.77 \\
\hline Labile aluminium & $\mu$ eq $\mathrm{L}^{-1}$ & 0.00 & 1.00 & 5.27 \\
\hline Dissolved organic carbon & $\mathrm{mg} \mathrm{L}^{-1}$ & 2.23 & 7.33 & 21.36 \\
\hline Gran alkalinity & $\mu$ eq $\mathrm{L}^{-1}$ & -8.50 & 30.80 & 104.92 \\
\hline
\end{tabular}

* Acid neutralising capacity (ANC) is estimated as the sum of base cations minus the sum of strong acid anions (see Eq. 1).

general circulation models under two emission scenarios of the Intergovernmental Panel on Climate Change (IPCC: Nakienovi et al., 2000). Future scenarios for runoff were obtained from the Finnish watershed simulation and forecasting system (WSFS, Vehviläinen and Huttunen, 2002). Finally, the potential influence of future changes in surface water DOC concentrations on lake acid status was also explored using simple empirical models.

\section{Study sites}

The acidification monitoring network (RMLA), maintained by SYKE, consists of 163 lakes located throughout Finland (Fig. 1). The lakes were subjectively chosen by expert judgement for use in national acidification studies. They were initially surveyed for chemistry during 1987 and have been monitored regularly since 1990 . The lakes are predominantly small (median area $=10 \mathrm{ha}$ ) headwater or seep- age lakes. Catchment characteristics were determined from topographic maps $(1: 20000)$. The terrestrial land cover is dominated by forests (median $=75 \%$ ) and peatlands (median $=15 \%$ ); the catchments are relatively undisturbed (only seven lakes have catchments with $>3 \%$ agricultural fields). All the lakes are acid-sensitive with low base cation concentrations, low alkalinity and sometimes elevated labile aluminium $\left(\mathrm{Al}^{3+}\right)$ concentrations (Mannio, 2001; Forsius et al., 2003; Table 1). Long-term annual precipitation ranges between 0.48 and $0.70 \mathrm{~m}$, temperature between -2.3 and $+4.4^{\circ} \mathrm{C}$, and catchment runoff between 0.24 and $0.42 \mathrm{~m}$ for the lake catchments (Table 1).

\section{Model description}

MAGIC is a lumped-parameter model of intermediate complexity, developed to predict the long-term effects of acidic deposition on soils and surface water chemistry. The model 


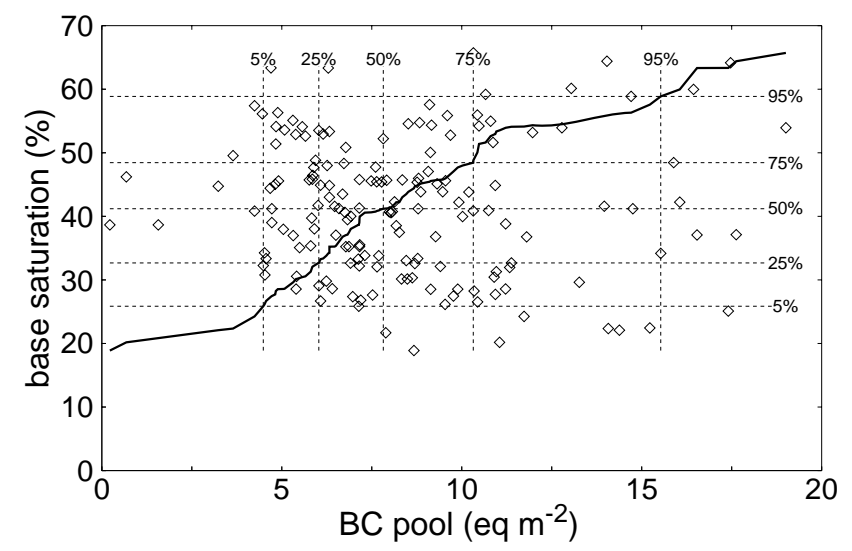

Fig. 2. Lumped average catchment base cation (BC) pool $\left(\mathrm{eq} \mathrm{m}^{-2}\right)$ versus percent base saturation for the 163 study sites. To aid interpretation, a "percentile grid" - i.e. selected percentiles values $(5 \%$, $25 \%$, median, $75 \%$ and $95 \%$ ) as thin dashed lines for both variables - is shown together with the "percentile-percentile curve" (thick solid line) connecting all percentiles of the respective distributions of the two variables, from the minima in the lower left to the maxima in the upper-right corner. This so-called "P-P-plot" reveals both the correlation structure of the two variables and allows an (approximate) determination of any percentile.

was first described by Cosby et al. (1985) and developments are reviewed in Cosby et al. (2001). The model predicts monthly and annual average concentrations of the major ions for soil solution and surface water chemistry. MAGIC represents the catchment with aggregated, uniform soil compartments (up to three), and a surface water compartment that can be either a lake or a stream. Time series inputs to the model include: deposition of ions from the atmosphere (wet plus dry deposition); discharge volume and flow routing within the catchment; biological production, removal and transformation of ions; internal sources and sinks of ions from weathering or precipitation reactions; and climate data. Constant parameters in the model include physical and chemical characteristics of the soils and surface waters, and thermodynamic constants. Soil base cation weathering rate and initial base saturation are calibrated using observed (or "target") values of surface water and soil chemistry for a specified period. In this instance calibration refers to an automated optimisation procedure that is a component of the MAGIC suite (MAGICOPT), generally used for regional applications. The minimum required site-measured target variables are: surface water concentrations for the major ions and soil exchangeable fractions for base cations, calcium $\left(\mathrm{Ca}^{2+}\right)$, magnesium $\left(\mathrm{Mg}^{2+}\right)$, sodium $\left(\mathrm{Na}^{+}\right)$and potassium $\left(\mathrm{K}^{+}\right)$. Prior processing, or calibration, of additional model data is also carried out as described under "model calibration". Further details are given in Aherne et al. (2008).

In the current study all catchments were represented by one soil compartment receiving deposition and releasing dis- charge to the lake compartment. The soil compartment represented the aggregated horizons of the catchment soils ( $\mathrm{min}$ eral and organic). Simulations were carried out using an annual time-step, with a number of simplifying assumptions applied consistently across all study lakes. Discharge volume and flow routing within the catchments were not varied during the calibration period; discharge was described using long-term means with $100 \%$ routed to the lake. Detailed process-oriented $\mathrm{N}$ dynamics were not modelled. The coefficient for in-lake $\mathrm{N}$ retention was set to $5 \mathrm{~m} \mathrm{yr}^{-1}$ for all lakes (Kelly et al., 1987) and terrestrial $\mathrm{N}$ retention was set to match observed lake concentrations (on average, $92 \%$ of the incoming $\mathrm{N}$ is retained in the catchment). Essential data for the regional application are time-series of annual atmospheric deposition (wet plus dry), biological production and removal, physical and chemical characteristics of the soils and lakes, and observed soil and lake chemistry for each study lake.

\section{Data sources}

\subsection{Lakes}

Chemical data for the RMLA lakes (Fig. 1) have been sampled (at least) annually since 1990. A sample of water from each lake was taken either from the middle of the lake $(1 \mathrm{~m}$ depth) or at the outlet each autumn during the thermal overturn phase (from early September in the north to mid November in the south). Chemical analyses are carried out by the laboratories of the Environmental Administration; samples are analysed for $\mathrm{Ca}^{2+}, \mathrm{Mg}^{2+}, \mathrm{K}^{+}, \mathrm{Na}^{+}$, chloride $\left(\mathrm{Cl}^{-}\right)$, $\mathrm{SO}_{4}^{2-}, \mathrm{NO}_{3}^{-}, \mathrm{NH}_{4}^{+}, \mathrm{Al}^{3+}$, DOC, $\mathrm{pH}$ and Gran alkalinity (Table 1) according to standardised methods (e.g., Forsius et al., 1990; Vuorenmaa and Forsius, 2008). Charge balance acid neutralizing capacity (ANC) was calculated as the sum of base cations minus the sum of acid anions:

$$
\begin{aligned}
\mathrm{ANC} & =\left(\mathrm{Ca}^{2+}+\mathrm{Mg}^{2+}+\mathrm{K}^{+}+\mathrm{Na}^{+}+\mathrm{NH}_{4}^{+}\right) \\
& -\left(\mathrm{SO}_{4}^{2-}+\mathrm{NO}_{3}^{-}+\mathrm{Cl}^{-}\right)
\end{aligned}
$$

The five-year period 1990-1994 was used to describe observed annual average lake concentration data (targets) for model calibration (calibration year $=1992$ ). A second fiveyear period (2000-2004: Table 1) was used to compare simulated and observed data. Median $\mathrm{pH}$ for the study lakes is 5.8 , Gran alkalinity is $30.8 \mu \mathrm{eq} \mathrm{L}{ }^{-1}$, DOC is $7.3 \mathrm{mg} \mathrm{L}^{-1}$ and base cations and sulphate are 162.8 and $45.8 \mu \mathrm{eq} \mathrm{L} \mathrm{L}^{-1}$, respectively, for the 2004-2004 averaging period (Table 1).

\subsection{Soils}

Soil physico-chemical properties were described using a network of 488 permanent plots located throughout Finland, established as part of the 8th national forest inventory. Samples of the humus layer and $0-5,5-20$ and $20-40 \mathrm{~cm}$ mineral soil 

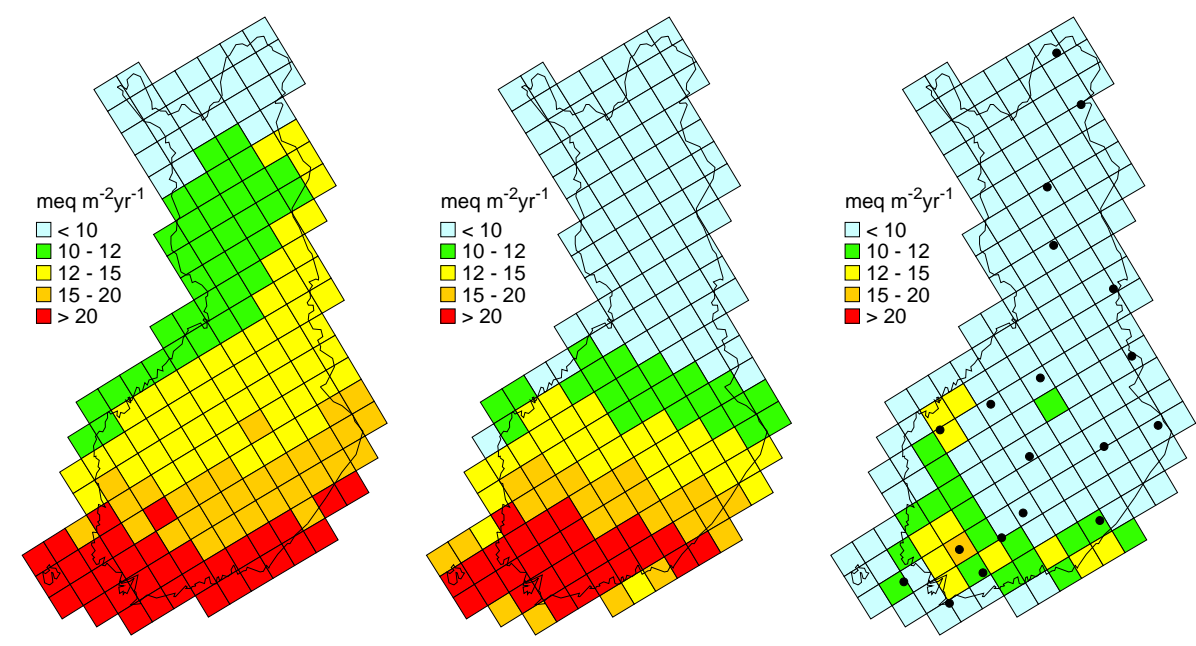

Fig. 3. Average annual deposition of sulphate (left), oxidised nitrogen (centre) and reduced nitrogen (right) in the year 2000 on the EMEP50 grid (Note: $1 \mathrm{meq}$ equals $16 \mathrm{mg}$ of $\mathrm{S}$ or $14 \mathrm{mg}$ of $\mathrm{N}$ ). The right map also shows the location of the 19 bulk deposition monitoring stations operated by the Finnish Environment Institute (SYKE; Vuorenmaa, 2004).

layers were taken systematically from five pits at each plot. From the $60-70 \mathrm{~cm}$ layer a single sample was taken from one of the five soil pits (Tamminen and Starr, 1990). Soils were analysed for exchangeable base cations, exchangeable acidity, organic matter, and carbon and nitrogen content according to standard procedures. Base saturation was calculated as the sum of base cations divided by the effective cation exchange capacity. Further details of sampling and analyses are given in Tamminen and Starr (1990).

The permanent soil plots do not, in general, lie within the study catchments. Soil properties were defined by interpolating (averaging) the three (geographically) nearest sites. Further, lumped soil physico-chemical data for each study catchment were derived by weighting soil properties by depth and density; e.g., for exchangeable $\mathrm{Ca}^{2+}\left(E_{\mathrm{Ca}}\right)$ :

$E_{\mathrm{Ca}}=\sum_{i=1}^{m} z_{i} \rho_{i} C E C_{i} E_{\mathrm{Ca}, i} / \sum_{i=1}^{m} z_{i} \rho_{i} C E C_{i}$

where $z_{i}, \rho_{i}, C E C_{i}$ and $E_{\mathrm{Ca}, i}$ refer to the thickness, bulk density, CEC and $E_{\mathrm{Ca}}$ of layer $i(i=1, \ldots m)$, respectively. Bulk densities were estimated from soil organic carbon content using empirical relationships by Van Wallenburg (1988) for the organic layer and Harrison and Bocock (1981) for the mineral layers, and from these a depth- and area-weighted catchment average was computed. The median soil depth for the study sites is $0.49 \mathrm{~m}$; median soil bulk density is $1009 \mathrm{~kg} \mathrm{~m}^{-3}$ (Table 1). Soil base saturation appears to be relatively high $($ median $=41 \%$ : Table 1 and Fig. 2 ); however, the total base cation pool (computed as the numerator in above Eq. 2) is low (Fig. 2). The median CEC for all study sites is 17 meq kg $\mathrm{g}^{-1}$ (Table 1 ).

\subsection{Forest uptake}

The long-term average annual net uptake of base cations $\left(\mathrm{Ca}^{2+}, \mathrm{Mg}^{2+}\right.$ and $\left.\mathrm{K}^{+}\right)$and $\mathrm{N}$ by forests in the lake catchments was calculated from the average annual volume growth and the nutrient concentrations in the removed (harvested) biomass (stem and bark). The average annual forest growth in Finland was estimated from the national forest inventory for 1970-1976 (Kuusela, 1977). The total forest area and total annual volume growth for three tree species (deciduous, spruce, pine) were given separately for 21 forest management districts with their average effective temperature sum (ETS) values. From these data the average annual growth for each tree species at any location in Finland as a function of the local ETS was estimated. Biomass densities of each tree species (Mälkönen, 1975; Rosén, 1982) were used to convert average annual volume growth to mass increments. Finally, the annual average nutrient uptake was calculated using data on nutrient contents in biomass based on field measurements (Mälkönen, 1975; Rosén, 1982; Olsson et al., 1993). Long-term average annual net uptake values are available for Finland with a spatial longitude-latitude resolution of $0.250^{\circ} \times 0.125^{\circ}$ (the HAKOMA grid; Johansson et al., 1990). Grid estimates were interpolated (distance averaged) and multiplied by the percentage of forest area to estimate the net uptake for each catchment. The median long-term average annual net uptake of base cations and $\mathrm{N}$ for the study sites are 6.4 and $5.3 \mathrm{meq} \mathrm{m}^{-2} \mathrm{yr}^{-1}$, respectively (Table 1).

\subsection{Deposition}

The spatial distribution of $\mathrm{S}$ and $\mathrm{N}$ deposition on a $50 \mathrm{~km} \times 50 \mathrm{~km}$ grid resolution (the EMEP50 grid) for the years 1990 and 2000 were taken from the output of the 

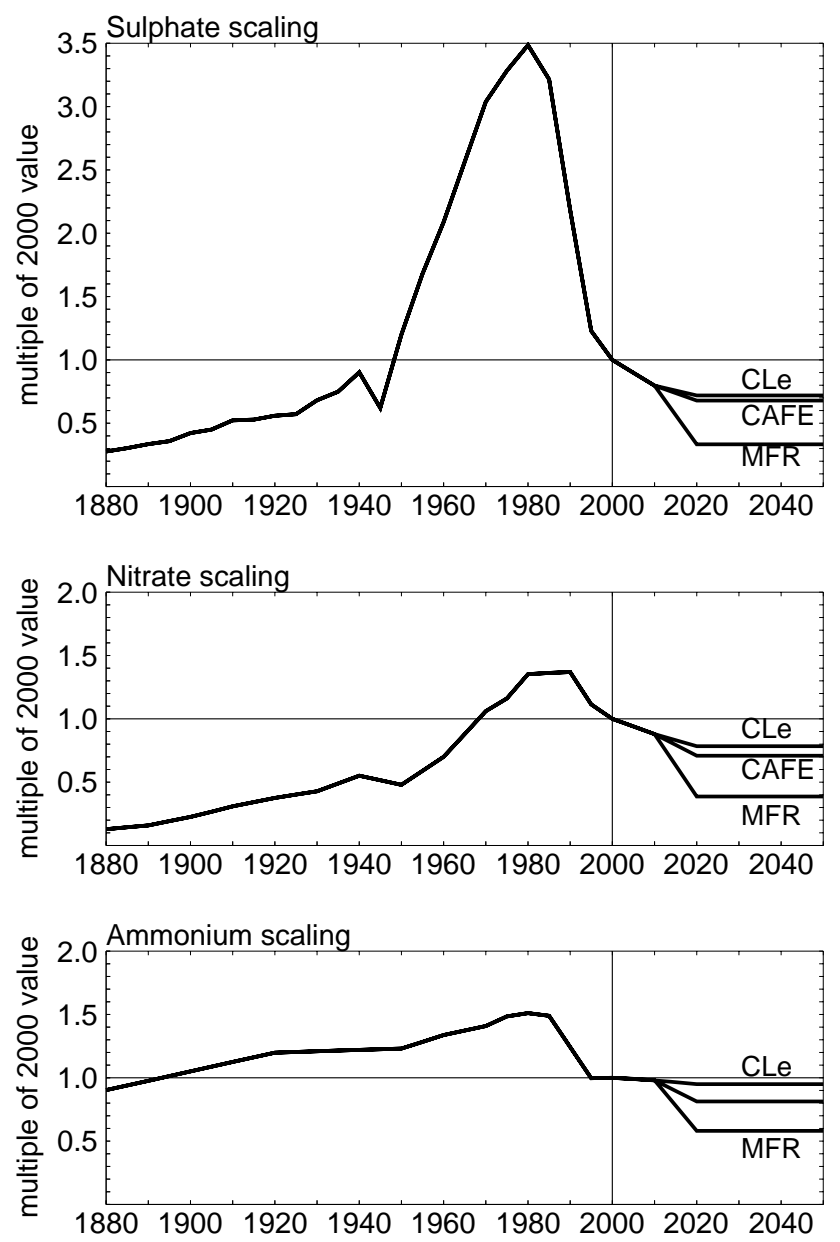

Fig. 4. Historical and future development of sulphate, nitrate and ammonium deposition in Finland. Between 2010 and 2020 three scenarios are introduced: CLe (highest), CAFE and MFR (lowest; see text for details). Note that these are scaling time-series, all having the value of one in 2000 . The absolute deposition for any year is obtained by multiplying the deposition at a given location in 2000 (from Fig. 3) with the fraction for the year shown in these sequences.

EMEP/MSC-W eulerian dispersion model (Tarrason et al., 2005). The deposition of $S$ and oxidised and reduced $\mathrm{N}$ in Finland show the well-known north-south gradient (Fig. 3). The depositions of base cations $\left(\mathrm{Ca}^{2+}, \mathrm{Mg}^{2+}, \mathrm{K}^{+}\right.$and $\mathrm{Na}^{+}$) and $\mathrm{Cl}^{-}$have been mapped on the HAKOMA grid for the years 1991-1995 by interpolating observations from a nation-wide network of (up to) 38 stations measuring monthly bulk deposition (Järvinen and Vänni, 1990). Both (deposition) data sources are consistent with observations at 19 bulk deposition monitoring stations operated by SYKE (Fig. 3; Vuorenmaa, 2004). Pre-calibration catchmentspecific estimates of base cation, $\mathrm{Cl}^{-}, \mathrm{S}$ and $\mathrm{N}$ deposition during the calibration year (1992) were estimated by interpolating (distance averaging) the surrounding grid values. Further details are given by Aherne et al. (2008).
Sulphur and $\mathrm{N}$ deposition history on the EMEP50 grid for the period 1880-1990 was obtained from Schöpp et al. (2003). The historical pattern is relatively consistent over Finland; therefore, a single relative deposition curve for each pollutant was used at all study sites (Fig. 4). The deposition sequences were scaled to unity for the year 2000 (reference year). Sulphur has by far the largest variation in the past, whereas ammonium varied the least (Fig. 4). Combining these curves with the depositions in the year 2000 (Fig. 3) allows the calculation of $\mathrm{S}$ and $\mathrm{N}$ deposition at every location in Finland at any time between 1880 and 2000. Calcium and $\mathrm{Mg}^{2+}$ deposition were assumed to follow the same historical sequence as $\mathrm{S}$, the remaining base cations and chloride were assumed constant throughout the simulation period.

\section{Model calibration}

Site-specific parameter files were prepared for each study site using catchment and soil physico-chemical characteristics based on, or estimated from, field observations (lake area, lake retention, soil bulk density, soil cation exchange capacity, etc), and considered "fixed" in the model (see Table 1). In addition, a number of default parameter values were uniformly applied across the region, e.g., the partial pressure of carbon dioxide in the soil was set at $\sim 15$ times atmospheric. Lake DOC concentrations and aluminium solubility constants were calibrated to lake $\mathrm{pH}$ and $\mathrm{Al}^{3+}$ concentrations, respectively. Chloride and $\mathrm{SO}_{4}^{2-}$ were assumed to be conservative with respect to input-output fluxes. The excess of outputs over inputs was principally attributed to unmeasured dry deposition. However, in general, lake $\mathrm{SO}_{4}^{2-}$ fluxes are consistent with deposition estimates. Further details are given in Aherne et al. (2008). Nitrogen $\left(\mathrm{NO}_{3}^{-}\right.$and $\mathrm{NH}_{4}^{+}$) transformation was described as a catchment net retention calculated simply as the difference between input and output flux for the calibration year. This percentage was assumed to be constant throughout the simulation.

Base cation weathering rates and initial soil exchangeable fractions were calibrated using MAGICOPT. The procedure uses numerical techniques to select parameter values that result in a minimum sum of squares error between simulated and observed target variables for each catchment. To account for uncertainty in a number of the fixed parameters (lake retention, lake area, soil depth, soil bulk density, cation exchange capacity and sulphate adsorption half saturation), a "fuzzy" optimisation method was employed. Multiple calibrations were carried out for each study lake; during each simulation the fixed parameters were randomly varied within specified uncertainty bands $( \pm 10 \%)$. In addition, uncertainty bands (or tolerance levels) were also applied to the target lake water $\left( \pm 2 \mu \mathrm{eq} \mathrm{L}^{-1}\right)$ and soil chemistry $( \pm 0.2 \%)$ variables. For each study lake 10 calibrations were performed, and any simulation that reproduced all target variables was considered successful. 
Table 2. Statistical summaries (5th percentile, median and 95th percentile) of the calibrated soil parameters (weathering rate, 1880 cation saturation, cation exchange selectivity coefficients, dissolved organic carbon and aluminium solubility coefficients) for the study sites ( $\mathrm{n}=163$; see Fig. 1 for locations).

\begin{tabular}{|c|c|c|c|c|}
\hline Calibrated parameter & Units & 5 percentile & Median & 95 percentile \\
\hline \multicolumn{5}{|l|}{ Weathering rate } \\
\hline Calcium & meq $\mathrm{m}^{-2} \mathrm{yr}^{-1}$ & 2.99 & 14.46 & 41.32 \\
\hline Magnesium & meq $\mathrm{m}^{-2} \mathrm{yr}^{-1}$ & 1.23 & 10.90 & 24.72 \\
\hline Sodium & meq $\mathrm{m}^{-2} \mathrm{yr}^{-1}$ & 0.84 & 7.79 & 18.89 \\
\hline Potassium & meq $\mathrm{m}^{-2} \mathrm{yr}^{-1}$ & 0.00 & 0.82 & 5.13 \\
\hline \multicolumn{5}{|l|}{ Initial cation saturation (1880) } \\
\hline Calcium & $\% \mathrm{CEC}$ & 19.44 & 31.39 & 47.96 \\
\hline Magnesium & $\% \mathrm{CEC}$ & 5.96 & 10.13 & 19.33 \\
\hline Sodium & $\%$ CEC & 3.49 & 5.36 & 8.01 \\
\hline Potassium & $\%$ CEC & 0.71 & 1.26 & 2.03 \\
\hline \multicolumn{5}{|l|}{ Exchange selectivity coefficients } \\
\hline Aluminium-calcium & $\log$ & -2.69 & 0.03 & 2.05 \\
\hline Aluminium-magnesium & $\log$ & -1.90 & 1.18 & 3.26 \\
\hline Aluminium-sodium & $\log$ & -4.79 & -2.86 & -1.25 \\
\hline Aluminium-potassium & $\log$ & -4.55 & -3.14 & -1.61 \\
\hline Dissolved organic carbon & $\mathrm{mmol} \mathrm{m}^{-3}$ & 2.64 & 37.29 & 98.19 \\
\hline Aluminium solubility coefficient & $\log$ & 8.14 & 9.12 & 10.12 \\
\hline
\end{tabular}

Ten calibrations were performed on simulations run from 1880 to 2000 using historical deposition sequences. The number of successful calibrations per study lake ranged from $3-10$, with the majority of lakes having $>5$ successful calibrations (155 lakes). Calibrated base cation weathering rates (median $=37 \mathrm{meq} \mathrm{m}^{-2} \mathrm{yr}^{-1}$ ) are similar to those for acid sensitive catchments in Europe and North America (Table 2; Watmough et al., 2005). Median percent base saturation in 1880 was approximately $7 \%$ greater than current $(48.1 \%$ and $41.2 \%$, respectively; see Tables 1 and 2). Goodness-of-fit for observed against predicted values was evaluated using model efficiency (100\% represents complete agreement: Janssen and Heuberger, 1995). There was excellent agreement between simulated and observed ANC for the calibration year (model efficiency $=100 \%$; Fig. 5). Simulated and observed ANC were also compared ten years beyond the calibration year: 2002 (mean of five-year period centred on 2002). In general, there is good agreement between simulated and observed ANC for 2002 (model efficiency $=88 \%$; Fig. 5). The simulated lake ANC is in general lower than the observed, which may be due to an underestimate of the $\mathrm{S}$ deposition reduction between 1992 and 2002 by the EMEP sequence (Fig. 4) compared with actual reductions. The largest deviations occur for lakes with the highest ANC $\left(>100 \mu \mathrm{eq} \mathrm{L}{ }^{-1}\right)$, which are not important with respect to acidification. Further details are given by Aherne et al. (2008).

\section{Future scenarios}

\subsection{Deposition scenarios}

Three future (2010-2100) scenarios for $\mathrm{S}$ and $\mathrm{N}$ deposition have been used in the current study: (i) a "Current Legislation" (CLe) scenario, which assumes the implementation of the 1999 Gothenburg Protocol of the LRTAP Convention as well as the EU National Emissions Ceiling (NEC) Directive; (ii) a scenario developed by the European Commission's "Clean Air for Europe" (CAFE) programme; and (iii) a "Maximum Feasible Reductions" (MFR) scenario, which assumes implementation of all technically feasible emission reduction measures by 2020 (Amann et al., 2005). All deposition scenarios follow a common sequence between 1880 and 2010, from 2010 the three scenarios are phased in linearly until 2020 and assumed constant thereafter (Fig. 3). In general, the CLe and CAFE scenarios show similar reductions, with CAFE showing slightly larger reductions (more so for $\mathrm{NH}_{4}^{+}$). The MFR scenario shows considerably greater reductions; relative to 2000, S deposition in 2020 is reduced by $67 \%$, with CLe and CAFE showing $28 \%$ and $32 \%$ reductions (Fig. 3).

\subsection{Climate and runoff scenarios}

Future climate (temperature and precipitation) was derived from the HadAM3 (Hadley Centre, UK) and ECHAM4/OPYC3 (Max Planck Institute, Germany) general circulation models (GCM) under two emission scenarios of 

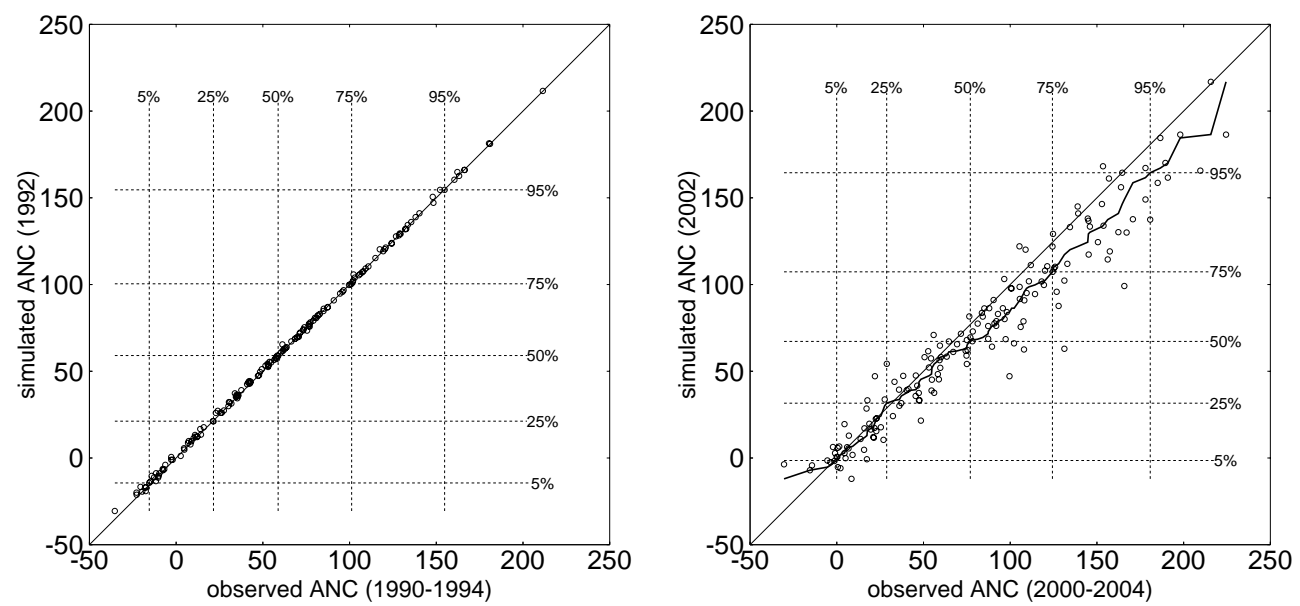

Fig. 5. Five-year mean observed ANC ( $\mu$ eq $\mathrm{L}^{-1}$ ) for the 163 study lakes in 1990-1994 (left) and 2000-2004 (right) compared with the simulated ANC for the years 1992 and 2002, respectively. Also shown are the 1:1-line, the percentile grid and the percentile-percentile curve (P-P-plot; see also Fig. 2).

the Intergovernmental Panel on Climate Change (IPCC: A2 and B2). The GCM outputs were downscaled to a 0.5 degree grid resolution using the Swedish Rossby Centre regional Atmosphere-Ocean (RCAO) model. In the present study, the combination giving the highest range of uncertainty was chosen, i.e., the A2 scenario results from ECHAM4/OPYC3 (highest predicted change) and B2 results from HadAM3 (lowest predicted change). The A2 scenario represents a more pessimistic future with high emissions of greenhouse gases, the B2 scenario is more optimistic with lower emission (Nakienovi et al., 2000). These scenarios have been uniformly chosen in the Euro-Limpacs project to reflect the uncertainty in the climate scenarios.

Present day (1961-1990) and future scenarios for catchment runoff were obtained from the Finnish watershed simulation and forecasting system (WSFS, Finnish version of the Swedish HBV-model system), which is used for operational hydrological forecasting (Vehviläinen and Huttunen, 2002). In the WSFS simulations, both the temperature and precipitation changes were assumed to directly follow the change given by the climate scenarios ("delta-change method"). Model output is provided as changes in temperature, precipitation and runoff with respect to the control period (1961-1990) for three 30-year periods: 2010-2039, 2040-2069 and 2070-2099. These data have been further interpolated to a $10 \mathrm{~km} \times 10 \mathrm{~km}$ grid covering Finland. For each study site, the value of the grid cell in which the lake was located was used.

Temperature is predicted to increase quite uniformly (5$7^{\circ} \mathrm{C}$ ) over the next 100 years, precipitation increases are also pronounced, but less uniform. Modelled runoff decreases at most sites, but the changes are quite small (Fig. 6) because higher temperatures "counter-act" higher precipitation by increased evapotranspiration. In the current study temperature and runoff were assumed to be constant until 2000 (reference year), change linearly between the midpoints of the periods (2025, 2055 and 2085), and remain constant thereafter. In contrast to the deposition scenarios, which use a common future sequence for all sites, individual temperature and runoff scenarios have been used for each study site.

\subsection{Aquatic DOC scenarios}

The reason for increases in DOC concentrations is currently under intense debate and several different hypotheses have been proposed (see above). Recent Finnish studies have suggested that temperature (Holmberg et al., 2006) and decreases in acidic deposition (primarily sulphate) are contributing factors (Vuorenmaa et al., 2006).

In the current study, an exploratory sensitivity analysis of the potential impact of future changes in surface water DOC concentrations on lake acidity status was carried out. Two (alternative) empirically based models related to changes in climate (temperature: T-model) and S deposition (S-model) were employed, reflecting the uncertainty in the mechanisms and drivers behind the DOC increases. The change in observed lake DOC concentrations between 1990 and 2000 was related to the observed change in S deposition as well as the change in temperature during the same period. For each lake change coefficients were estimated:

$k_{S, l}=\frac{\Delta \mathrm{DOC}_{l}}{\Delta S_{\mathrm{dep}, l}} \quad$ and $\quad k_{T, l}=\frac{\Delta \mathrm{DOC}_{l}}{\Delta T_{l}} \quad l=1, \ldots, 163$

For the latter, high-resolution European climate data from the Climate Research Unit in the United Kingdom (Mitchell et al., 2004) were employed. These coefficients were then used in simple site-specific linear models to "forecast" DOC 
concentration at any future time $t$ (the subscript " 0 " refers to the 2000 values):

$$
\begin{aligned}
& \mathrm{S}-\text { model }: \operatorname{DOC}_{l}(t)=\mathrm{DOC}_{l, 0}+k_{S, l} \cdot\left(S_{\mathrm{dep}, l}(t)-S_{\mathrm{dep}, l, 0}\right) \\
& \mathrm{T}-\text { model }: \operatorname{DOC}_{l}(t)=\mathrm{DOC}_{l, 0}+k_{T, l} \cdot\left(T_{l}(t)-T_{l, 0}\right)
\end{aligned}
$$

Negative DOC values predicted by these models were set to zero; and in the T-model the predicted DOC value was limited to a maximum of $60 \mathrm{mg} \mathrm{L}^{-1}$ (Fig. 7). Sulphate deposition and temperature in 2100 were obtained from the deposition and climate scenario described above. The sulphate (S)-model predicted modest increases in DOC in 2100 under the CLe scenario (median DOC increased from 7.3 to $7.8 \mathrm{mg} \mathrm{L}^{-1}$ ). In contrast, the temperature (T)-model predicted considerable increases in lake DOC concentrations under the CLe and A2 scenarios (median DOC increased from 7.3 to $11.6 \mathrm{mg} \mathrm{L}^{-1}$ : Fig. 7). The modelled DOC concentrations for each lake were incorporated into MAGIC to estimated lake $\mathrm{pH}$ in 2100.

\section{Results and discussion}

\subsection{Influence of deposition on recovery}

Future soil and surface water chemistry for each lake were simulated for the period 2000-2100. The multiple simulation results for each lake were combined using median statistics. Future recovery patterns (until the year 2100) were evaluated using three key indicators: $\mathrm{ANC}$ and $\mathrm{pH}$ in lake water and base saturation in the catchment soils (Fig. 8 and Table 3). Lake ANC and $\mathrm{pH}$ are standard indicators used in acidification studies, as both are strongly indicative of biological recovery (Hutchinson et al., 1989; Lien et al., 1996). In addition, ANC is the most widely used chemical criterion in critical load calculations for surface waters (Henriksen et al., 1995). Base saturation is a key indicator for the chemical conditions in soil.

The reduction in $\mathrm{S}$ deposition is the main driver of acidification recovery in Finland (Forsius et al., 2003; Posch et al., 2003). The median nitrate concentration of the modelled lakes is only $0.61 \mu \mathrm{eq} \mathrm{L} \mathrm{L}^{-1}$ (Table 1) and increasing trends in nitrate for the RMLA lakes have not been observed. Future changes in $\mathrm{N}$ emissions are therefore not expected to have any major impact on the acidity status of Finnish lakes (Forsius et al., 2003), and are therefore given limited attention in the present study.

Both the CLe and CAFE scenarios showed very marginal recovery in lake chemistry between 2000 and 2100 (Fig. 8 and Table 3). The median of the simulated ANC for the CLe/CAFE scenarios increased by $2.76 / 4.04 \mu \mathrm{eq} \mathrm{L}^{-1}$. Simulated median $\mathrm{pH}$ increased by approximately 0.1 of a $\mathrm{pH}$ unit for both scenarios (0.12/0.13 for CLe/CAFE). Median soil base saturation similarly showed limited recovery, with increases $<1 \%$. The marginal recoveries are (initially) somewhat surprising considering that $\mathrm{S}$ deposition is reduced by
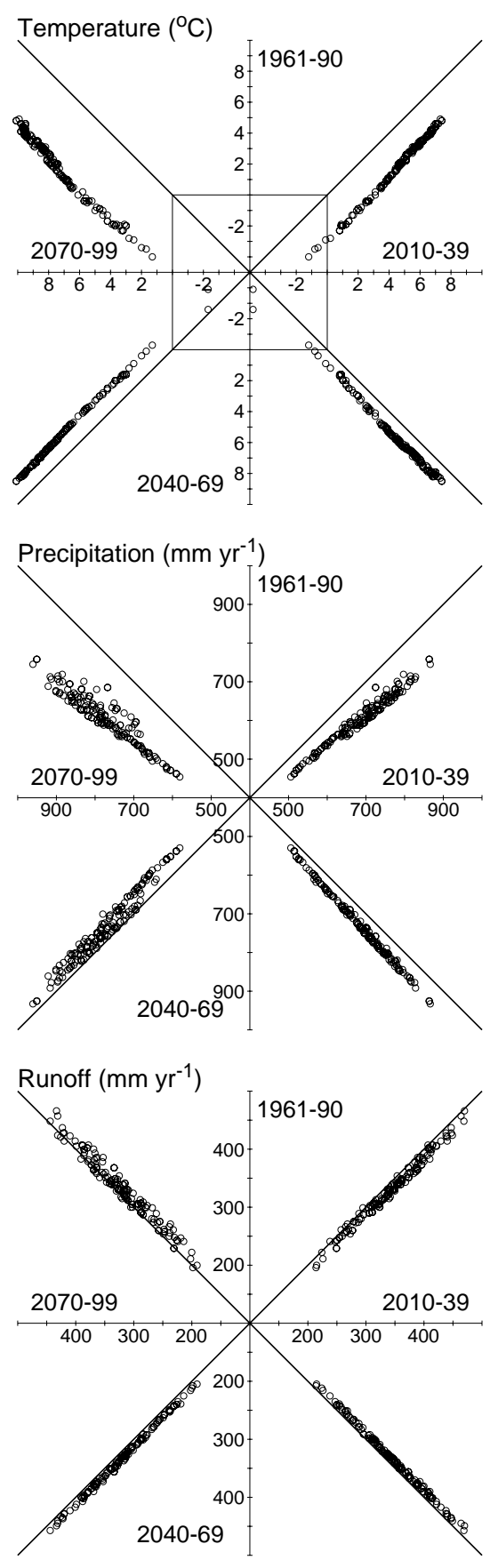

Fig. 6. Multiple correlations ("windmill plots") of temperature, precipitation and runoff at the 163 study sites for the control period (1961-1990) and three future 30-year periods under the A2 scenario. Starting at the top and proceeding clock-wise, the "windmill plots" provide a comprehensive overview of the temporal changes between successive periods as well as the overall change between the first and last period in the last (top-left) quadrant.

28 and $32 \%$ relative to 2000 under the CLe and CAFE scenarios, respectively. However, the largest reductions in S depositions, and largest recoveries, occurred during the 1980s 

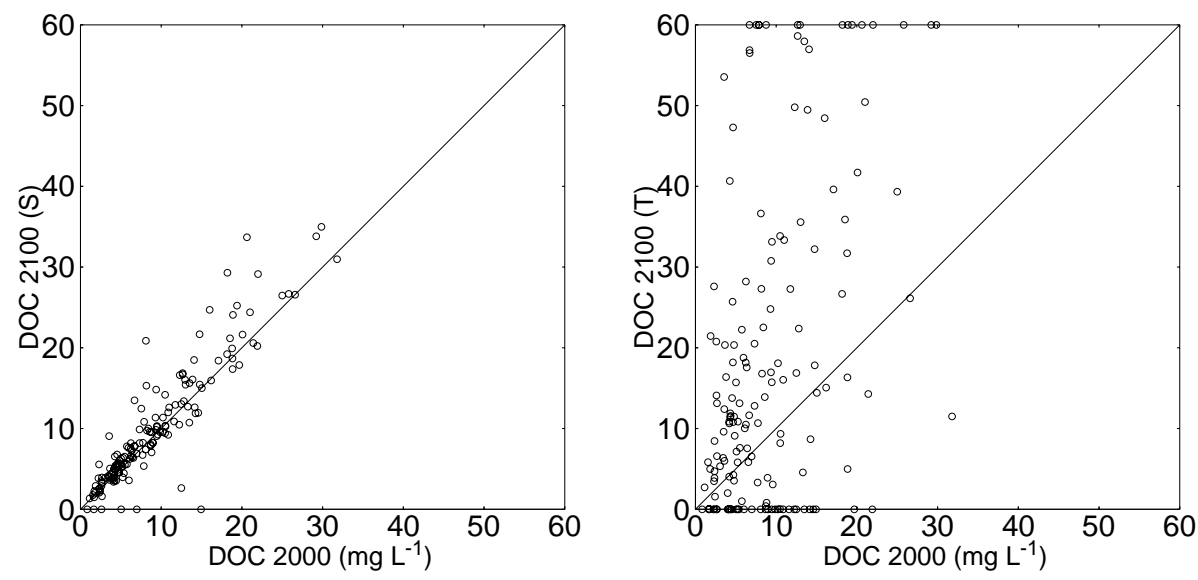

Fig. 7. Lake dissolved organic carbon (DOC) concentrations measured in 2000 against DOC estimated for 2100 with the "S-model" (left) and the "T-model" (right). The 1:1-line is also shown.

and 1990s (Fig. 4). The future recovery of surface water chemistry will continue, but more slowly than during the previous decades. In addition, future reductions in emissions are likely to stop soil acidification (base cation depletion).

Posch et al. (2003) used the SMART model to predict the possible recovery of 36 acid-sensitive Finnish headwater lakes, located mainly in southern parts of the country. The model was used to simulate soil and water chemistry until 2030 under a "current legislation scenario". In concert with the current study, Posch et al. (2003) indicated that most of the catchment soils would show very little change in base saturation, whereas the positive trends in lake ANC, which have been observed over the past decade, would continue into the future, albeit at a slower pace. Posch et al. (2003) also predicted that during 2010-2030 all lakes will have reached a positive ANC, a pre-requisite for the recovery of fish populations. In the current study, based on a larger and more spatially representative data set, four lakes have negative ANC in 2030, and 28 have ANC $<20 \mu \mathrm{eq} \mathrm{L}^{-1}$. Wright et al. (2005) applied the MAGIC and SMART models to twelve acidsensitive surface water regions in Europe. The model results indicated that even after complete implementation of the Gothenburg protocol and other current legislation, acidification with commensurate adverse biological effects will continue to be a significant problem in southern Norway, southern Sweden, the Pennines in the UK, the Tatra Mountains (Slovakia), and the Italian Alps. In each of these regions more than 5\% of the lakes will not meet the ANC criterion to protect sensitive aquatic organisms.

In contrast to the other two scenarios, the MFR scenario showed significant recovery potential; ANC increased by $10.18 \mu \mathrm{eq} \mathrm{L} \mathrm{L}^{-1}, \mathrm{pH}$ by 0.28 units and percent base saturation by $3.35 \%$. Recent studies of future global atmospheric environment similarly indicated that improvements in (global) air quality could only be obtained through the introduction of stringent abatement technologies (MFR: Dentener et al., 2006).

\subsection{Influence of climate on recovery}

The direct influence of climate was investigated by incorporating future changes in temperature and catchment runoff, under the IPCC A2 and B2 emission scenarios, into model simulations. Climate showed very little influence on recovery when compared to constant climate under CLe (Table 3 ). The A2 and B2 emission scenarios were selected to reflect the widest range of future changes. Despite this, both scenarios showed very little difference in simulated soil and surface water chemistry (Table 3 ). The results are not surprising; incorporation of temperature changes has little influence on the process descriptions included in MAGIC and similar hydro-chemical models. Temperature primarily influences the calculation of internal (temperature-dependent) equilibrium constants. Catchment runoff changes can potentially have a significant influence on recovery (especially in relation to drought: Aherne et al., 2004, 2006); however, both the $\mathrm{A} 2$ and $\mathrm{B} 2$ scenarios indicate very little difference in future runoff across Finland (Fig. 6).

Wright et al. (2006) used the MAGIC model to evaluate the effect of climate change on the modelled recovery of soil and surface water from acidification. A simple sensitivity analyses was used at 14 intensively studied sites in Europe and eastern North America. Wright et al. (2006) indicated that predictions for future recovery require actual climate scenarios downscaled from GCMs, as in the current study. More importantly, the results of their simple sensitivity analyses potentially indicated limitations in current modelling structures to represent climate-induced changes. Climateinduced changes in processes are generally not incorporated in current versions of acidification models. This is largely due to the lack of knowledge on the detailed cause and mechanisms linking changes in climate to changes in soil and water chemistry. Ultimately the mechanisms and rates by which climate changes affect key biogeochemical processes need to be incorporated directly into process-oriented models such 

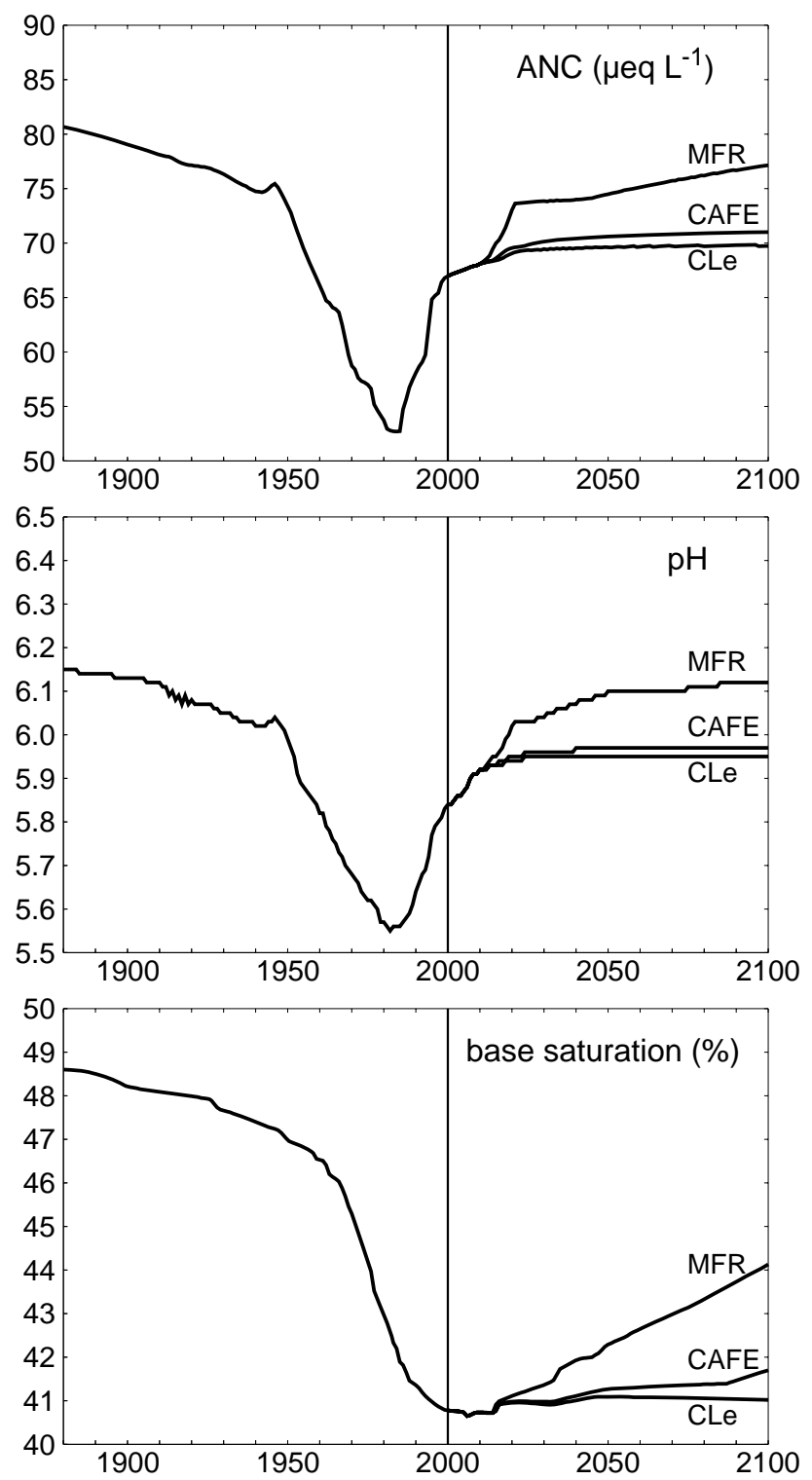

Fig. 8. Temporal development of the median of ANC (top) and $\mathrm{pH}$ (centre) in the lake water as well as the catchment base saturation (bottom) of the 163 lakes for the three deposition scenarios CLe, CAFE and MFR (see Fig. 4).

as MAGIC (Wright et al., 2006). Furthermore, to simulate changes in seasonal processes, such as snow cover dynamics, drought and storm events, a finer time resolution (at least monthly) is necessary.

\subsection{Influence of dissolved organic carbon on recovery}

Skjelkvåle et al. (2005) presented four major climate-related factors that may potentially confound chemical and biological recovery: (i) increased frequency and severity of sea-salt episodes; (ii) increased frequency and severity of drought; (iii) increased turnover of organic carbon; and (iv) increased

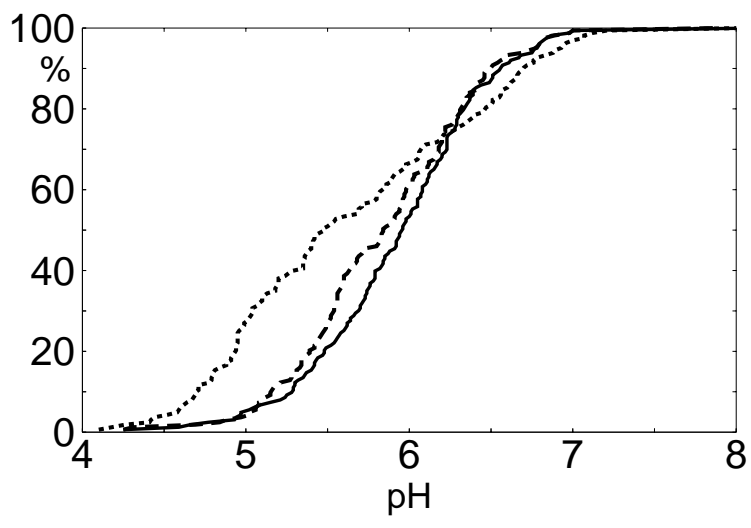

Fig. 9. Cumulative distribution function of $\mathrm{pH}$ of the 163 study lakes in the year 2100 for the CLe scenario: with no climate change and constant DOC (solid line), and for the two DOC models: the Smodel (dashed line) and the T-model under the A2 scenario (dotted line).

mineralization of nitrogen. Further Wright et al. (2006) suggested that the modelling of recovery from acidification should take into account possible concurrent climate changes and focus especially on the climate-induced changes in organic acids and nitrogen retention.

In the current study, the influence of DOC concentrations (organic acids) on surface water acidity was investigated using two simple empirical models related to temperature and $\mathrm{S}$ deposition change (Fig. 9). Simulated median $\mathrm{pH}$ in 2100 for the S-model (under CLe) was $0.12 \mathrm{pH}$ units lower than the CLe scenario (under constant DOC). Median pH was identical to the base calibration in 2000, suggesting that the modest recovery in $\mathrm{pH}$ resulting from reductions in $\mathrm{S}$ deposition (under CLe) may be offset by increases in DOC concentration (owing to the reduced $\mathrm{S}$ deposition). The simulated median $\mathrm{pH}$ for the T-model (under CLe and A2) was significantly reduced; $\mathrm{pH}$ in 2100 was estimated to be 5.47 (Table 3). This suggests that temperature may potentially be a significant confounding factor in the recovery of surface waters from acidification (Fig. 9). Recent studies in Finland have suggested that both temperature (Holmberg et al., 2006) and decreases in S deposition (Vuorenmaa et al., 2006) influence the concentrations of DOC in surface waters.

Several hypotheses have been proposed to explain the increases in DOC, which have been observed across Europe and eastern North America during the past few decades. Enhanced decomposition of peat soils due to increased temperature has been proposed (Freeman et al., 2001a, b), as well as elevated atmospheric carbon dioxide levels and consequent stimulation of primary production (Freeman et al., 2004). Others have cited changes in hydrological regimes (Tranvik and Jansson, 2002; Hejzlar et al., 2003) and the frequency of severe droughts (Worrall et al., 2004). The decrease in acidic deposition and the consequent decrease in acidity variables and/or ionic strength have been proposed as 
Table 3. Median values of simulated soil base saturation (BS), lake acid neutralising capacity (ANC) and lake pH in 2000 and 2100 under three emission, two climate and two DOC scenarios.

\begin{tabular}{lccc}
\hline Scenario & $\begin{array}{c}\text { Soil BS } \\
\text { \% CEC }\end{array}$ & $\begin{array}{c}\text { Lake ANC } \\
\mu \mathrm{eq} \mathrm{L}^{-1}\end{array}$ & $\begin{array}{c}\text { Lake pH } \\
\mathrm{pH} \text { units }\end{array}$ \\
\hline $\begin{array}{l}\text { Base calibration scenario (2000) } \\
\text { Historical emissions }\end{array}$ & 40.78 & 66.97 & 5.84 \\
$\begin{array}{l}\text { Emission scenarios (2100) } \\
\text { Current Legislation (CLe) }\end{array}$ & 41.02 & 69.73 & 5.96 \\
Clean Air for Europe (CAFE) & 41.70 & 71.01 & 5.97 \\
Maximum Feasible Reductions (MFR) & 44.13 & 77.15 & 6.12 \\
Climate scenarios (2100) & & & \\
A2 (under CLe) & 41.01 & 69.74 & 5.99 \\
B2 (under CLe) & 40.43 & 69.38 & 5.97 \\
DOC scenarios (2100) & & & \\
Sulphate model (under CLe) & - & - & 5.84 \\
Temperature model (under CLe and A2) & - & - & 5.47 \\
\hline
\end{tabular}

other contributing factors (e.g., Hejzlar et al., 2003; Stoddard et al., 2003; Evans et al., 2005, 2006; Vuorenmaa et al., 2006). Land-use change and disturbance may also result in increased decomposition of soil organic matter and release of DOC (Kortelainen and Saukkonen, 1998; Neal et al., 2005). Lake DOC concentrations may further be controlled by photo-mineralization (Hudson et al., 2003). It is likely that different factors act simultaneously, and that the relative significance of these factors varies between sites and regions.

In the current study, changes in temperature and $\mathrm{S}$ deposition were used to model future DOC concentrations. However, (increased) cloudiness showed the largest changes during the last decade (data not shown). Increased cloudiness may drive reduced photo-mineralization. Unfortunately, estimates of future cloudiness were not available for DOC modelling. Using a process-based model of carbon biogeochemistry, Futter et al. (2008) have recently proposed that increased DOC concentrations in a small Finnish lake were at least partly due to decreased photo-mineralization rates.

It is inevitable that there are uncertainties associated with the application of models such as the one used here. These can be roughly grouped into two categories: (a) uncertainties due the model structure (conceptualisation), and (b) uncertainties in the model parameters and input data. Although some of the process descriptions used in simple hydrochemical models have been called into question (e.g., Neal, 1997), the MAGIC model has been used across a wide range of study sites and deposition regimes, and it has proven itself as a reliable tool for simulating the impact of deposition reductions. In general, it is mainly the lack of site-specific input data which limit the applications on a regional scale, especially a more explicit consideration of the spatial heterogeneity of catchments. A different issue is the impacts of climate change: MAGIC (and related models) are not explicitly conceptualised to include climate-sensitive processes, and it is hoped that exercises like the present one will encourage the improvement of the models in this respect. Furthermore, when more observations become available, they should be used for validation or, since validation in a strict sense is not possible (see, e.g., Beven, 1993), for gaining confidence in model simulations - or suggest modifications. However, comprehensive uncertainty analyses are time- and resourceintensive, a fact which decision makers tend to forget when requesting information on uncertainties.

\section{Conclusions}

The impact of future acid deposition and climate change scenarios on soil and surface water chemistry was evaluated for 163 lakes in Finland using MAGIC. Simulations suggested that only the maximum (technically) feasible emission reduction scenario would result in significant recovery of soils and surface waters from acidification, and would bring back water quality close to pre-acidification values. The direct influence of climate change (temperature and runoff) had very little impact on model simulations for Finland, based on current process descriptions. However, climate-induced changes may have a significant influence on the recovery of surface waters from acidification. Since there is indication that changes in dissolved organic carbon, induced by reductions in acid deposition or increases in temperature, may potentially influence the recovery of surface waters from acidification, two simple empirical DOC models were used to explore these influences. Theses model experiments showed that changes in both sulphur deposition and temperature could have a confounding influence on the recovery of surface waters from acidification, and that the corresponding increases in DOC concentrations may offset the recovery in $\mathrm{pH}$ due to 
reductions in acidifying depositions. It has to be noted that climate-induced changes in processes are generally not explicitly incorporated in current versions of most acidification models. Therefore, it is recommended to incorporate into currently used acidification models the drivers and mechanisms by which climate changes affect the key biogeochemical processes.

Acknowledgements. This study was carried out as part of the Commission of European Communities project Euro-Limpacs (Integrated project to evaluate impacts of global change on European freshwaters ecosystems, GOCE-CT-2003-505540, http://www.eurolimpacs.ucl.ac.uk). This research was undertaken, in part, thanks to funding from the Canada Research Chairs Program and an NSERC Discovery grant. M. Starr (University of Helsinki), P. Tamminen (Finnish Forest Research Institute), J. Vuorenmaa (Finnish Environment Institute) and M. Johansson (UNECE, Geneva) are acknowledged for providing data for model parameterisation.

Edited by: P. Dillon and R. F. Wright

\section{References}

Aherne, J., Dillon, P. J., and Cosby, B. J.: Acidification and recovery of aquatic ecosystems in south-central Ontario, Canada: regional application of the MAGIC model, Hydrol. Earth Syst. Sci., 7, 561-573, 2003, http://www.hydrol-earth-syst-sci.net/7/561/2003/.

Aherne, J., Larssen, T., Dillon, P. J., and Cosby, B. J.: Effects of climate events on elemental fluxes from forested catchments in Ontario, Canada: modelling drought-induced redox processes, Water Air Soil Poll. Focus, 4, 37-48, 2004

Aherne, J., Larssen, T., Cosby, B. J., and Dillon, P. J.: Climate variability and forecasting surface water recovery from acidification: modelling drought-induced sulphate release from wetlands, Sci. Total Environ., 365, 186-199, 2006.

Aherne, J., Posch, M., Forsius, M., Vuorenmaa, J., Tamminen, P., Holmberg, M., and Johansson, M.: Modelling the hydrogeochemistry of acid-sensitive catchments in Finland under atmospheric deposition and biomass harvesting scenarios, Biogeochemistry, accepted, 2008.

Alveteg, M., Sverdrup, H., and Warfvinge P.: Regional assessment of the temporal trends in soil acidification in southern Sweden, using the SAFE model, Water Air Soil Poll., 85, 2509-2514, 1995.

Amann, M., Bertok, I., Cabala, R., Cofala, J., Heyes, C., Gyarfas, F., Klimont, Z., Schöpp, W., and Wagner, F.: A final set of scenarios for the Clean Air For Europe (CAFE) Programme, Final Report to the European Commission, International Institute for Applied Systems Analysis, Laxenburg, Austria, 103 pp., http://www.iiasa.ac.at/rains, last access: 22 February 2008, 2005.

Beier, C., Moldan, F., and Wright, R. F.: Terrestrial ecosystem recovery - modelling the effects of reduced acidic inputs and increased inputs of sea salts induced by global change, Ambio, 32, 275-282, 2003.

Beven, K.: Prophecy, reality and uncertainty in distributed hydrological modelling, Adv. Water Resour., 16, 41-51, 1993.
Cosby, B. J., Hornberger, G. M., Galloway, J. N., and Wright, R. F.: Modeling the effects of acid deposition: Assessment of a lumped parameter model of soil water and streamwater chemistry, Water Resour. Res., 21, 51-63, 1985.

Cosby, B. J., Ferrier, R. C., Jenkins, A., and Wright, R. F.: Modelling the effects of acid deposition: refinements, adjustments and inclusion of nitrogen dynamics in the MAGIC model, Hydrol. Earth Syst. Sci., 5, 499-517, 2001, http://www.hydrol-earth-syst-sci.net/5/499/2001/.

Dentener, F., Stevenson, D., Ellingsen, K., vanNoije, T., Schultz, M., Amann, M., Atherton, C., Bell, N., Bergmann, D., Bey, I., Bouwman, L., Butler, T., Cofala, J., Collins, B., Drevet, J., Doherty, R., Eickhout, B., Eskes, H., Fiore, A., Gauss, M., Hauglustaine, D., Horowitz, L., Isaksen, I. S. A., Josse, B., Lawrence, M., Krol, M., Lamarque, J. F., Montanaro, V., Muller, J. F., Peuch, V. H., Pitari, G., Pyle, J., Rast, S., Rodriguez, J., Sanderson, M., Savage, N. H., Shindell, D., Strahan, S., Szopa, S., Sudo, K., VanDingenen, R., Wild, O., and Zeng, G.: The global atmospheric environment for the next generation, Environ. Sci. Technol., 40, 3586-3594, 2006.

De Vries, W., Posch, M., and Kämäri, J.: Simulation of the longterm soil response to acid deposition in various buffer ranges, Water Air Soil Poll., 48, 349-390, 1989.

De Vries, W., Reinds, G. J., Posch, M., and Kämäri, J.: Simulation of soil response to acidic deposition scenarios in Europe, Water Air Soil Poll., 78, 215-246, 1994.

EMEP: EMEP Assessment, Part I, European Perspective, Norwegian Meteorological Institute, Oslo, Norway, http://www.emep. int, last access: 22 February 2008, 2004.

Evans, C. D.: Modeling the effects of climate change on an acidic upland stream, Biogeochemistry, 74, 21-46, 2005.

Evans, C. D., Monteith, D. T., and Cooper, D. M.: Long-term increases in surface water dissolved organic carbon: Observations, possible causes and environmental impacts, Environ. Pollut., 137, 55-71, 2005.

Evans, C. D., Chapman, P. J., Clark, J. M., Monteith, D. T., and Cresser, M. S.: Alternative explanations for rising dissolved organic carbon export from organic soils, Glob. Change Biol., 12, 2044-2053, 2006.

Forsius, M., Malin, V., Mäkinen, I., Mannio, J., Kämäri, J., Kortelainen, P., and Verta, M.: Finnish lake acidification survey: design and random selection of lakes, Environmetrics, 1, 79-99, 1990.

Forsius, M., Johansson, M. Posch, M., Holmberg, M., Kämäri, J., Lepistö, A., Roos, J., Syri, S., and Starr, M.: Modelling the effects of climate change, acidic deposition and forest harvesting on the biogeochemistry of a boreal forested catchment in Finland, Boreal Environ. Res., 2, 129-143, 1997.

Forsius, M., Alveteg, M., Jenkins, A., Johansson, M., Kleemola, S., Lükewille, A., Posch, M., Sverdrup, H., and Walse, C.: MAGIC, SAFE and SMART model applications at integrated monitoring sites: Effects of emission reduction scenarios, Water Air Soil Poll., 105, 21-30, 1998.

Forsius, M., Vuorenmaa, J., Mannio, J., and Syri, S.: Recovery from acidification of Finnish lakes: regional patterns and relations to emission reduction policy, Sci. Total Environ., 310, 121132, 2003.

Freeman, C., Evans, C. D., Monteith, D. T., Reynolds, B., and Fenner, N.: Export of organic carbon from peat soil, Nature, 412, 
785-785, 2001a.

Freeman, C., Ostle, N., and Kang, H.: An enzymic "latch" on a global carbon store, Nature, 409, 149, 2001b.

Freeman, C., Fenner, N., Ostle, N. J., Kang, H., Dowrick, D. J., Reynolds, B., Lock, M. A., Sleep, D., Hughes, S., and Hudson, J.: Export of dissolved organic carbon from peatlands under elevated carbon dioxide levels, Nature, 430, 195-198, 2004.

Futter, M., Starr, M., Forsius, M., and Holmberg, M.: Modelling long-term patterns of dissolved organic carbon concentrations in the surface waters of a boreal catchment, Hydrol. Earth Syst. Sci., 12 , this special issue, 2008.

Harrison, A. F. and Bocock, K. L.: Estimation of soil bulk-density from loss-of-ignition values, J. Appl. Ecol., 8, 919-927, 1981.

Hejzlar, J., Dubrovský, M., Buchtele, J., and Ružièka, M.: The apparent and potential effects of climate change on the inferred concentration of dissolved organic matter on a temperate stream (The Mãlse River, South Bohemia), Sci. Total Environ., 310, 143-152, 2003.

Henriksen, A., Posch, M., Hultberg, H., and Lien, L.: Critical loads of acidity for surface waters - can the $\mathrm{ANC}_{\text {limit }}$ be considered variable?, Water Air Soil Poll., 85, 2419-2424, 1995.

Hettelingh, J.-P., Posch, M., Slootweg, J., Reinds, G. J., Spranger, T., and Tarrason, L.: Critical loads and dynamic modelling to assess European areas at risk of acidification and eutrophication, Water Air Soil Poll. Focus, 7, 379-384, 2007.

Holmberg, M., Rankinen, K., Johansson, M., Forsius, M., Kleemola, S., Ahonen, J., and Syri, S.: Sensitivity of soil acidification model to deposition and forest growth, Ecol. Model., 135, 311-325, 2000.

Holmberg, M., Forsius, M., Starr, M., and Huttunen, M.: An application of artificial neural net-works to carbon, nitrogen and phosphorus concentrations in three boreal streams and impacts of climate change, Ecol. Model., 195, 51-60, 2006.

Hudson, J. J., Dillon, P. J., and Somers, K. M.: Long-term patterns in dissolved organic carbon in boreal lakes: the role of incident radiation, precipitation, air temperature, southern oscillation and acid deposition, Hydrol. Earth Syst. Sci., 7, 390-398, 2003, http://www.hydrol-earth-syst-sci.net/7/390/2003/.

Hutchinson, N. J., Holtze, K. E., Munro, J. R., and Pawson, T. W.: Modifying effects of life stage, ionic strength and post-exposure mortality on lethality of $\mathrm{H}^{+}$and $\mathrm{Al}$ to lake trout and brook trout, Aquat. Toxicol., 15, 1-26, 1989.

Iivonen, P., Kämäri, J., and Posch, M.: Modelling the chemical response of a moderately acidified catchment in southern Finland to decreased sulphur deposition, Aqua Fennica, 23, 235-249, 1993.

Janssen, P. H. M. and Heuberger, P. S. C.: Calibration of processoriented models, Ecol. Model., 83, 55-66, 1995.

Järvinen, O. and Vänni, T.: Bulk deposition chemistry in Finland, in: Acidification in Finland, edited by: Kauppi, P., Anttila, P., and Kenttämies, K., Springer, Berlin Heidelberg, 151-165, 1990.

Johansson, M., Kämäri, J., Pipatti, R., Savolainen, I., Tuovinen, J.P., and Tähtinen, M.: Development of an integrated model for the assessment of acidification in Finland, in: Acidification in Finland, edited by: Kauppi, P., Anttila, P., and Kenttämies, K., Springer, Berlin Heidelberg, 1171-1193, 1990.

Jylhä, K., Tuomenvirta, H., and Ruosteenoja, K.: Climate change projections for Finland during the 21st century, Boreal Environ. Res., 9, 127-152, 2004.
Kämäri, J., Posch, M., Kähkönen, A.-M., and Johansson, M.: Modeling potential long-term responses of a small catchment in Lapland to changes in sulfur deposition, Sci. Total Environ., 160/161, 687-701, 1995.

Kämäri, J., Rankinen, K., Finér, L., Piirainen, S., and Posch, M.: Modelling the response of soil and runoff chemistry to forest harvesting in a low deposition area (Kangasvaara, Eastern Finland), Hydrol. Earth Sys. Sci., 2, 485-495, 1998.

Kelly, C. A., Rudd, J. W. M., Hesslein, R. H., Schindler, D. W., Dillon, P. J., Driscoll, C. T., Gherini, S. A., and Hecky, R. E.: Prediction of biological acid neutralization in acid-sensitive lakes, Biogeochemistry, 3, 129-140, 1987.

Kortelainen, P. and Saukkonen, S.: Leaching of nutrients, organic carbon and iron from Finnish forestry land, Water Air Soil Poll., 105, 239-250, 1998.

Kuusela, K.: Increment and timber assortment structure and their regionality of the forests of Finland in 1970-1976, Finnish Forest Research Institute, Helsinki, Finland, Folia Forestalia 320, 31 pp., 1977 (in Finnish with English summary).

Larssen, T.: Model prognoses for future acidification recovery of surface waters in Norway using long-term monitoring data, Environ. Sci. Technol., 39, 7970-7979, 2005.

Lien, L., Raddum, G. G., Fjellheim, A., and Henriksen, A.: A critical limit for acid neutralizing capacity in Norwegian surface waters, based on new analyses of fish and invertebrate responses, Sci. Total Environ., 177, 173-193, 1996.

Mälkönen, E.: Annual primary production and nutrient cycle in some Scots pine stands, Helsinki, Finland, Communicationes Instituti Forestalis Fenniae 84, 87 pp., 1975.

Mannio, J.: Recovery pattern from acidification of headwater lakes in Finland, Water Air Soil Poll., 130, 1427-1432, 2001.

Mitchell, T. D., Carter, T. R., Jones, P. D., Hulme, M., and New, M.: A comprehensive set of high-resolution grids of monthly climate for Europe and the globe: the observed record (19012000) and 16 scenarios (2001-2100), Tyndall Centre Working Paper 55, Norwich, United Kingdom, 30 pp., available at: http: //www.cru.uea.ac.uk/cru/data/hrg.htm, last access: 22 February 2008, 2004.

Nakićenović, N., Alcamo, J., Davis, G., De Vries, B., Fenhann, J., Gaffin, S., Gregory, K., Grübler, A., Jung, T. Y., Kram, T., La Rovere, E. L., Michaelis, L., Mori, S., Morita, T., Pepper, W., Pitcher, H., Price, L., Raihi, K., Roehrl, A., Rogner, H.-H., Sankovski, A., Schlesinger, M., Shukla, P., Smith, S., Swart, R., Van Rooijen, S., Victor, N., and Dadi, Z.: Emissions Scenarios. A Special Report of Working Group III of the Intergovernmental Panel on Climate Change, Cambridge University Press, 599 pp., 2000.

Neal, C.: A view of water quality from the Plynlimon watershed, Hydrol. Earth Syst. Sci., 1, 743-75, 1997, http://www.hydrol-earth-syst-sci.net/1/743/1997/.

Neal, C., Robson, A. J., Neal, M., and Reynolds, B.: Dissolved organic carbon for upland acidic and acid sensitive catchments in mid-Wales, J. Hydrol., 304, 203-230, 2005.

Olsson, M., Rosén, K., and Melkerud, P.-A.: Regional modelling of base cation losses from Swedish forest soils due to whole-tree harvesting, Appl. Geochem., Special Issue 2, 189-194, 1993.

Posch, M., Forsius, M., Johansson, M., Vuorenmaa, J., and Kämäri, J.: Modelling the recovery of acid-sensitive Finnish headwater lakes under present emission reduction agreements, Hydrol. 
Earth Syst. Sci., 7, 484-493, 2003,

http://www.hydrol-earth-syst-sci.net/7/484/2003/.

Rask, M., Pöysä, H., Nummi, P., and Karppinen, C.: Recovery of perch (Perca fluviatilis) in an acidified lake and subsequent responses in macroinvertebrates and the goldeneye (Bucephala clangula), Water Air Soil Poll., 130, 1367-1372, 2001.

Rosén, K.: Supply, loss and distribution of nutrients in three coniferous forest watersheds in central Sweden. Reports in Forest Ecology and Forest Soils 41, Swedish University of Agricultural Sciences, Uppsala, 1982.

Roulet, N. and Moore, T. R.: Browning the waters, Nature, 444, 283-284, 2006.

Ruoho-Airola, T., Anttila, P., Tuovinen, J.-P., and Salmi, T.: Assessment Report on the Finnish EMEP data 1980-2000. Publications on Air Quality No. 3, Finnish Meteorological Institute, Helsinki, 21 pp., 2003.

Schöpp, W., Posch, M., Mylona, S., and Johansson, M.: Trends in acid deposition (1880-2030) for sensitive freshwater regions in Europe, Hydrol. Earth Syst. Sci., 7, 436-446, 2003, http://www.hydrol-earth-syst-sci.net/7/436/2003/.

Skjelkvåle, B. L., Evans, C., Larssen, T., Hindar, A., and Raddum, G. G.: Recovery from acidification in European surface waters: a view to the future, Ambio, 32, 170-175, 2003.

Skjelkvåle, B. L., Stoddard, J. L., Jeffers, J. N. R., Tørseth, K., Høgåsen, T., Bowman, J., Mannio, J., Monteith, D., Mosello, R., Rogora, M., Rzychon, D., Veselý, J., Wieting, J., Wilander, A., and Worsztynowicz, A.: Regional scale evidence for improvements in surface water chemistry 1990-2001, Environ. Pollut., 137, 165-176, 2005.

Stoddard, J. L., Jeffries, D. S., Lükewille, A., Clair, T. A., Dillon, P. J., Driscoll, C. T., Forsius, M., Johannessen, M., Kahl, J. S., Kellogg, J. H., Kemp, A., Mannio, J., Monteith, D., Murdoch, P. S., Patrick, S., Rebsdorf, A., Skjelkvåle, B. L., Stainton, M. P., Traaen, T. S., van Dam, H., Webster, K. E., Wieting, J., and Wilander, A.: Regional trends in aquatic recovery from acidification in North America and Europe 1980-95, Nature, 401, 575-578, 1999.

Stoddard, J. L., Karl, J. S., Deviney, F. A., DeWalle, D. R., Driscoll, C. T., Herlihy, A. T., Kellogg, J. H., Murdoch, P. S., Webb, J. R., and Webster, K. E.: Response of Surface Water Chemistry to the Clean Air Act Amendments of 1990, Report EPA 620/R-03/001, United States Environmental Protection Agency, North Carolina, 2003, 78 pp., 2003.

Tamminen, P. and Starr, M. R.: A survey of forest soil properties related to soil acidification in southern Finland, in: Acidification in Finland, edited by: Kauppi, P., Anttila, P., and Kenttämies, K., Springer, Berlin Heidelberg, 231-247, 1990.

Tarrason, L., Benedictow, A., Fagerli, H., Jonson, J. E., Klein, H., Van Loon, M., Simpson, D., Tsyro, S., Vestreng, V., Wind, P., Forster, C., Stohl, A., Amann, M., Cofala, J., Langner, J., Andersson, C., and Bergström, R.: Transboundary acidification, eutrophication and ground level ozone in Europe in 2003, EMEP Report 1/2005, Norwegian Meteorological Institute, Oslo, Norway, http://www.emep.int, last access: 22 February 2008, 2005.
Tranvik, L. J. and Jansson, M.: Climate change - terrestrial export of organic carbon, Nature, 415, 861-862, 2002.

Van Wallenburg, C.: The density of peaty soils, Internal Report, Soil Survey Institute, Wageningen, The Netherlands, 5 pp., 1988 (in Dutch).

Vehviläinen, B. and Huttunen, M.: The Finnish watershed simulation and forecasting system (WSFS), Publication of the 21st conference of Danube countries on the hydro-logical forecasting and hydrological bases of water management, 2002.

Vuorenmaa, J.: Long-term changes of acidifying deposition in Finland (1973-2000), Environ. Pollut., 128, 351-362, 2004.

Vuorenmaa, J., Forsius, M., and Mannio, J.: Increasing trends of total organic carbon concentrations in small forest lakes in Finland from 1987 to 2003, Sci. Total Environ., 365, 47-65, 2006.

Vuorenmaa, J. and Forsius, M.: Recovery of acidified Finnish lakes: trends, patterns and dependence of catchment characteristics, Hydrol. Earth Syst. Sci., 12, this special issue, 2008.

Warfvinge, P., Holmberg, M., Posch, M., and Wright, R. F.: The use of dynamic models to set target loads, Ambio, 21, 369-376, 1992.

Warfvinge, P., Falkengren-Grerup, U., Sverdrup, H., and Andersen, B.: Modelling long-term cation supply in acidified forest stands, Environ. Pollut., 80, 209-221, 1993.

Watmough, S. A., Aherne, J., Alewell, C., Arp, P. A., Bailey, S., Clair, T. A., Dillon, P. J., Duchesne, L., Eimers, M. C., Fernandez, I., Foster, N., Larssen, T., Miller, E., Mitchell, M., and Page, S.: Sulphate, nitrogen and base cations at 21 forested catchments in Canada, the United States and Europe, Environ. Monitor. Assess., 109, 1-36, 2005.

Worrall, F., Harriman, R., Evans, C. D., Watts, C. D., Adamson, J., Neal, C., Tipping, E., Burt, T., Grieve, I., Monteith, D., Naden, P. M., Nisbet, T., Reynolds, B., and Stevens, P.: Trends in dissolved organic carbon in UK in rivers and lakes, Biogeochemistry, 70, 369-402, 2004.

Wright, R. F., Camarero, L., Cosby, B. J., Ferrier, R. C., Forsius, M., Helliwell, R., Jenkins, A., Kopáèek, J., Larssen, T., Majer, V., Moldan, F., Posch, M., Rogora, M., and Schöpp, W.: Recovery of acidified European surface waters, Environ. Sci. Technol., 39, 64A-72A, 2005.

Wright, R. F., Aherne, J., Bishop, K., Camarero, L., Cosby, B. J., Erlandsson, M., Evans, C. D., Forsius, M., Hardekopf, D., Helliwell, R., Hruska, J., Jenkins, A., Moldan, F., Posch, M., and Rogora, M.: Modelling the effect of climate change on recovery of acidified freshwaters: relative sensitivity of individual processes in the MAGIC model, Sci. Total Environ., 365, 154-166, 2006. 